\title{
Marine sedimentary record of Meltwater Pulse 1a along the NW Barents Sea continental margin
}

\author{
Renata Giulia Lucchi ${ }^{1} \cdot$ Leonardo Sagnotti $^{2} \cdot$ Angelo Camerlenghi $^{1} \cdot$

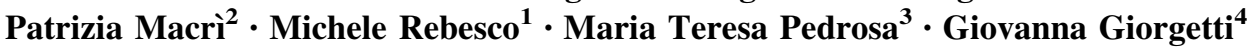

Received: 11 September 2015/Accepted: 14 October 2015/Published online: 20 November 2015

(c) The Author(s) 2015. This article is published with open access at Springerlink.com

\begin{abstract}
The upper continental slope of the StorfjordenKveithola Trough Mouth Fans (NW Barents Sea) contains a several m-thick late Pleistocene sequence of plumites composed of laminated mud interbedded with sand/silt layers. Radiocarbon ages revealed that deposition occurred during about 130 years at a very high sedimentation rate of $3.4 \mathrm{~cm} \mathrm{a}^{-1}$, at about $7 \mathrm{~km}$ from the present shelf break. Palaeomagnetic and rock magnetic analyses confirm the existence of a prominent, short-living sedimentary event. The plumites appear laterally continuous and were correlated with the sedimentary sequences described west of Svalbard and neighboring glacial depositional systems representing a major event at regional scale appointed to correspond to the deep-sea sedimentary record of Meltwater Pulse-1a. We also present new sedimentological and geochemical insights, and multi-beam data adding information on the palaeoenvironmental characteristics during MWP-1a and ice sheet decay in the NW Barents Sea.
\end{abstract}

Keywords Meltwater Pulse 1a $\cdot$ Plumites $\cdot$ NW Barents Sea $\cdot$ Arctic

Renata Giulia Lucchi

rglucchi@ogs.trieste.it

1 OGS (Istituto Nazionale di Oceanografia e di Geofisica Sperimentale), Borgo Grotta Gigante, 42C, 34010 Sgonico, TS, Italy

2 Istituto Nazionale di Geofisica e Vulcanologia (INGV), Via di Vigna Murata 605, 00143 Rome, Italy

3 Instituto Andaluz de Ciencias de la Tierra, CSIC-Universidad de Granada, Avda de las Palmeras 4,

18100 Armilla, Granada, Spain

4 Dipartimento di Scienze della Terra, Università di Siena, via Laterina 8, 53100 Siena, Italy

\section{Introduction}

\section{Meltwater Pulse 1a}

A meltwater pulse (MWP) is a short-lived, global acceleration in sea-level rise resulting from intense front- and/or subglacial meltwater release, and/or surging ice streams into oceans and iceberg discharge during ice sheets disintegration [9]. It has been calculated that the rate of global sea-level rise during meltwater pulses could have been as high as $60 \mathrm{~mm} \mathrm{a}^{-1}$ during less than 500 years [29].

The existence of a pulsing mode for global sea-level rise after LGM, was discovered through the study of drowned late Quaternary reef-crest sequences cored in tropical areas (Barbados, [29]; Caribbean-Atlantic reef province, [10]; Tahiti, [3, 63]; Sunda Shelf, [32], Hawaii, [92]; among others). Although high-resolution radiocarbon and ${ }^{230} \mathrm{Th}$ dating of coral skeletons permit precise dating of the events, diffuse neo-tectonic uplift of these areas often led to controversial correlating results and difficult calculation of the events' magnitude.

Four main meltwater pulses have been pointed to have occurred during the last deglaciation phase: MWP-19 ka, also known as MWP- $1 \mathrm{a}_{0}$, about 19 cal ka BP [15, 93]; MWP-1a, 14.650-14.310 cal a BP [24]; MWP-1b, $11.500-11.000 \mathrm{cal}$ a B.P. [4]; and MWP-1c at about $8.000 \mathrm{cal}$ a BP $[11,33]$. Of these events, MWP-1a was possibly the most prominent leading to a global sea-level rise of about $20 \mathrm{~m}$ in the course of $340 \mathrm{a}\left(5.9 \mathrm{~cm} \mathrm{a}^{-1}\right.$, [24]).

Evidences of the existence MWP-1a have been found in many low-latitude areas but straightforward evidence is still lacking in polar areas where the event is thought to have originated. 
An on-going controversy concerns the identification of the trigger area and mechanisms responsible for MWP-1a ([1, 5, 6, 16-18, 20, 30, 31, 47, 65, 71, 81, 84, 89, 91], among others). Four ice sheets are considered as possible candidates responsible for shaping the global sea-level curve: the Laurentide, Fennoscandian, Barents and Antarctic ice sheets. Simulation of ocean-ice sheet interactions indicates that different meltwater sources should leave a geographically distinctive 'sea-level fingerprint' due to ice unloading histories and gravitational pull between the shrinking ice masses and oceanic water-masses variations [18, 22, 62].

Scarce and ambiguous evidences of MWP-1a imprints in the polar areas are puzzling and do not help resolve the controversy on its origin.

In this study, we present marine sedimentary evidence of MWP-1a recorded in the deep-sea sedimentary sequence of the Trough Mouth Fan (TMF) offshore the Storfjorden and Kveithola palaeo ice streams (Fig. 1). The deep-sea areas of polar continental margins, beyond the continental shelf brake controlled by ice grounding, are characterized by low-energy continuous sediment accumulation unaffected by glacial erosion, thus providing a valuable marine sedimentary record of ice sheet dynamics. While Lucchi et al. [58] gave a complete account of all the recovered sedimentary units in the studied area, we here focus on the interlaminated plumite unit and its significance as sedimentological signature of Meltwater Pulse 1a.

\section{Geological and oceanographic characteristics of the study area}

The Storfjorden and Kveithola TMF depositional systems are located south of the Spitsbergen Island in the NW Barents Sea [38, 51], (Fig. 1). Seismo-stratigraphic information in this area suggests that the onset of glacially influenced sedimentation occurred since about $1.8 \mathrm{Ma}$, when the Barents Sea Ice Sheet reached the continental shelf edge [39, 45]. Reconstruction of the late Pleistocene and Holocene depositional processes of the marine sedimentary record of the Storfjorden and Kveithola TMFs has been described in Lucchi et al. [58] and it is briefly summarized in the following (Fig. 2).

The older parts of the studied sediment cores contain mass transport deposits (MTD) emplaced during LGM, consisting of highly consolidated glacigenic diamicton (Fig. 2a) and normally consolidated debris flows derived
Fig. 1 Location map of the studied area with indication of the main palaeo ice streams and sediment cores location. Gray hued bathymetry was acquired during the SVAIS and EGLACOM cruises that is superimposed on IBCAO data [41]. Adapted from Camerlenghi et al. [12]
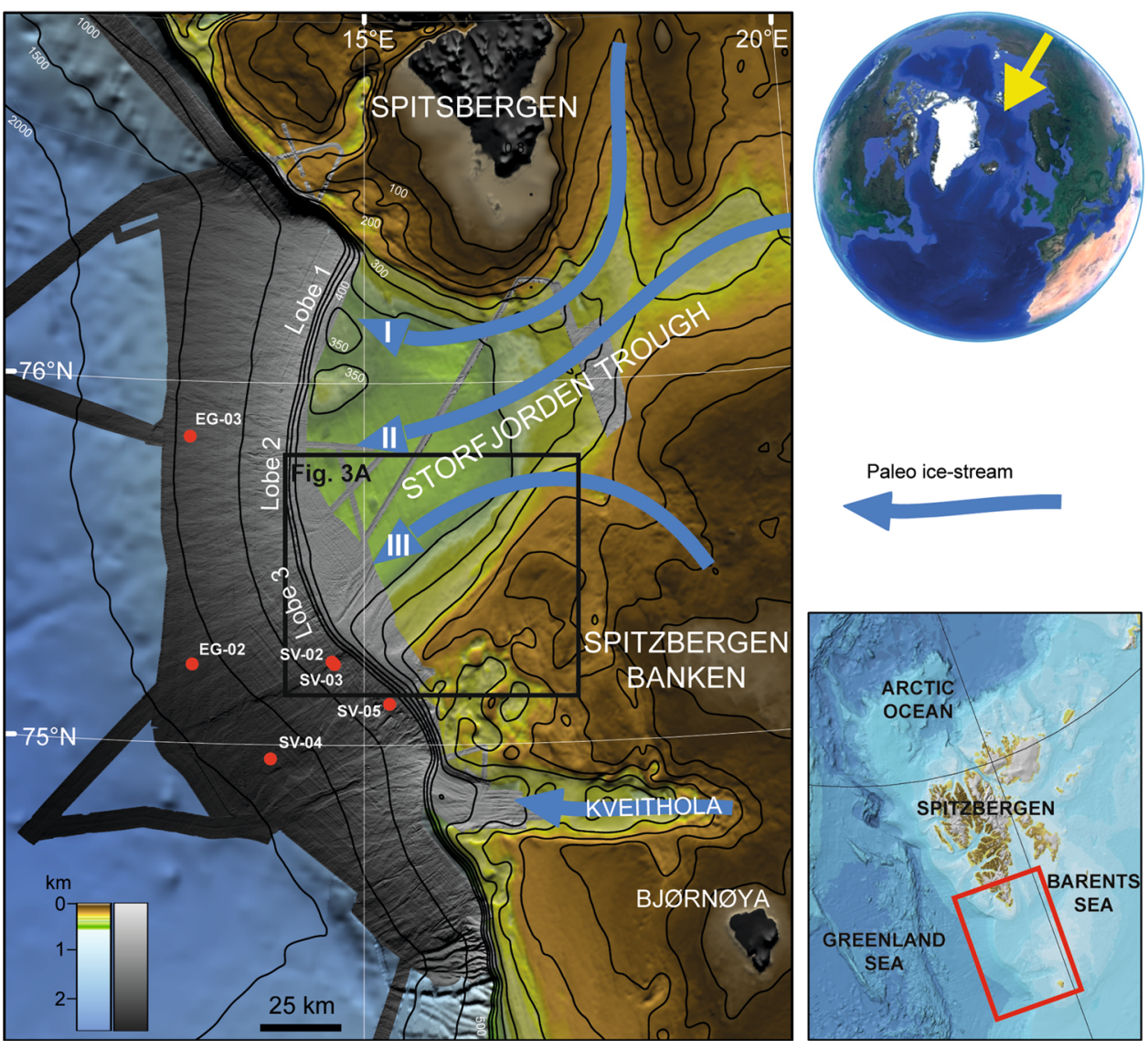
Fig. 2 Sediment facies and related depositional processes on the Storfjorden and Kveithola TMFs after LGM. The figure reports a synthetic interpretative lithological log, the radiographs and photos of the identified sediment facies after [58]

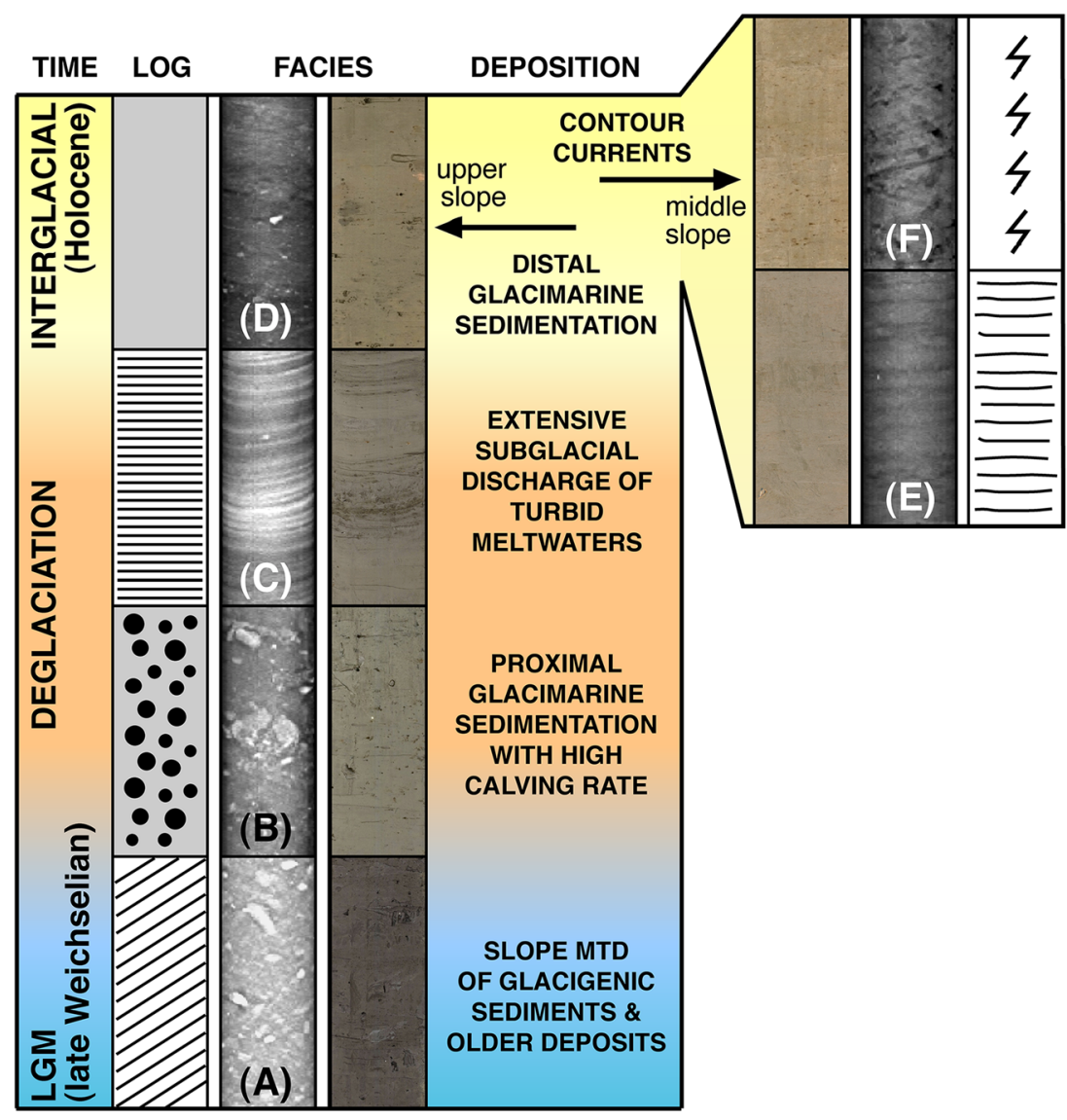

from the down-slope transport of glacigenic sediments locally incorporating older stratigraphic intervals.

Above the LGM deposits, are proximal glacimarine sediments containing abundant Ice Rafted Debris (IRD) deposited between 20-19 and 17-16 cal ka BP (Fig. 2b). The former interval contains an oxidized layer at its base holding evidences of sea-ice free/seasonal conditions (abundant planktonic foraminifera).

The glacimarine sediments are overlain by a progressively fining-up sequence of interlaminated sediments consisting of laminated mud interbedded with sand/silt layers (Fig. 2c). The interlaminated sediments are several $\mathrm{m}$-thick on the upper slope, and only a few $\mathrm{cm}$-thick on the middle slope. Sedimentological and compositional characteristics suggest that deposition occurred under the effects of extensive subglacial meltwaters (plumites, [58]).

On the upper slope, the top boundary of the interlaminated sediments has a sharp contact with bioturbated and slightly laminated distal glacimarine sediments (Fig. 2d) indicating the presence of bottom currents and palaeo-environmental conditions favorable to bioactivity. On the contrary, a massive IRD layer and distal glacimarine sediments overlie the interlaminated facies on the middle slope. The Holocene sequence on the middle slope consists of diatom-bearing crudely laminated sediments (Fig. 2e), and foraminifera/nannofossils-rich, heavily bioturbated sediments both deposited under the effect of bottom currents (contourites, Fig. 2f) associated with the warm, moderately saline Western Spitsbergen Current (WSC) deriving from the North Atlantic Current. This current flows northward along the continental slope transporting heat to the Arctic area.

\section{Materials and methods}

Bathymetric, sub-bottom profiling data, and sediment cores are the result of the merging of two data sets collected during two cruises.

BIO Hespérides IPY Cruise SVAIS (Longyearbyen, July 29-August 17, 2007). Bathymetry was acquired with multi-beam echo-sounder Simrad EM1002S. Data were logged using Simrad's Mermaid system and processed with Caris HIPS and SIPS V 6.1.

Sub-bottom profiling employed a hull-mounted Kongsberg TOPAS PS 18 parametric profiler using two primary frequencies ranging between 16 and $22 \mathrm{kHz}$. Cores were obtained with piston coring. 
R/V OGS Explora IPY Cruise EGLACOM (Kristiansund, July 07-August 04, 2008). Bathymetry was acquired with multi-beam echo-sounder Reson MB8150 operating at a mean frequency of $12 \mathrm{kHz}$, and MB8111, operating at a mean frequency of $100 \mathrm{kHz}$. Data were logged and processed with the Reson PDS2000V 2.5.3.2 software. Subbottom profiling employed a hull-mounted Benthos CAP6600 profiler, using a sweep of acoustic frequencies ranging between 2 and $7 \mathrm{kHz}$. Cores were obtained by gravity coring.

The final bathymetric digital terrain model was produced from the combined data set with $75 \mathrm{~m}$ grid spacing. Sub-bottom profiles from both surveys were imported in Seismic Micro-Technology's Kingdom Suite 8.3 software. In addition, regional bathymetric imaging was obtained from the Olex Ocean DTM ${ }^{\circledR}$.

The sediment cores (Table 1) were logged through an X-ray CT scan and an Avaatech XRF-core scan for chemical composition of the sediments. For this contribution we considered the down-core trends of Si (silica) content as proxy of the quartz content (terrigenous input) rather than amorphous silica forming diatoms frustules (assumption made after sediments microscope investigation); the $\mathrm{Cl}$ (chlorine) content was associated with the water content; the $\mathrm{Sr}$ (strontium) content was used as indicator of bio-productivity in place of barium that in the Arctic areas is often of detrital origin; and the S (sulfur) content, commonly associated to oxygen depleted environments.

Discrete samples collected at every $5-10 \mathrm{~cm}$ resolution were analyzed for water content, clay mineral analyses, total and organic carbon $\left(\mathrm{C}_{\text {tot }}, \mathrm{C}_{\mathrm{org}}\right)$ and total nitrogen $\left(\mathrm{N}_{\text {tot }}\right)$ content. For this study, we considered only the distribution of the smectite content indicated to be, in the studied area, a proxy of Atlantic Water strength [43], whereas the $\mathrm{C}_{\text {org }} / \mathrm{N}_{\text {tot }}$ ratio was used to distinguish between marine and continental-derived organic matter according to Meyers [61]. Details on the analytical procedure applied for geochemistry and clay mineral analyses are indicated in Lucchi et al. [58].

Palaeomagnetic investigations were performed on u-channels collected from undisturbed sediments. The lowfield magnetic susceptibility $(k)$ and the natural remanent magnetization (NRM) were measured at $1 \mathrm{~cm}$ spacing. The NRM was then stepwise demagnetized by alternating field (AF) up to $100 \mathrm{mT}$. The characteristic remnant magnetization (ChRM) has been isolated for each measured interval and its direction determined by fitting a leastsquare line on stepwise AF data with principal component analysis, according to Kirschvink [44]. The maximum angular deviation was then computed for each determined ChRM direction. Since the cores were not azimuthally oriented, the ChRM declination trends obtained for each u-channel have been arbitrarily rotated to align their average value with the true north.

From individual characteristic remnant magnetization directions, we calculated the corresponding Virtual Geomagnetic Pole (VGP), under the assumption of a geocentric axial dipole field.

The VGP scatter $(S)$ during an established time interval was estimated by the angular standard deviation of the VGP distribution during an established interval of time. In order to filter out large deviations that may not be representative of genuine PSV, we applied a cut-off angle to the computed VGPs following the iterative approach described by Vandamme [86]. Additional details on the palaeomagnetic analytical methodology applied are reported in [73].

The age model used for this study follows Sagnotti et al. [73], and Lucchi et al. [58], relied on rocks palaeomagnetic parameters and radiocarbon dating analyses (Table 2) calibrated with the calibration software program Calib 6.0 [82], using the marine09 calibration curve [70], and applying an average marine regional reservoir effect $\Delta \mathrm{R}=84 \pm 23$ (south of Svalbard). The mean values of the calibrated age range of $\pm 1 \sigma$ were then normalized to calendar year.

\section{Results}

\section{Outer shelf iceberg scours}

Sets of large parallel furrows are observed on the northern flank of Spitsbergen Bank in water depths between 350 and $390 \mathrm{~m}$ (Fig. 3). The furrows are 10-15 m deep with respect

Table 1 Core location

\begin{tabular}{lllclc}
\hline Core ID & Lat N & Lon E & Depth $(\mathrm{m})$ & Location & Lenght $(\mathrm{m})$ \\
\hline SV-02 & $75^{\circ} 13.707^{\prime}$ & $14^{\circ} 35.960^{\prime}$ & 743 & Upper-slope & 6.41 \\
SV-03 & $75^{\circ} 13.352^{\prime}$ & $14^{\circ} 37.249^{\prime}$ & 761 & Upper-slope & 6.42 \\
SV-04 & $74^{\circ} 57.425^{\prime}$ & $13^{\circ} 53.972^{\prime}$ & 1839 & Middle-slope & 3.03 \\
SV-05 & $75^{\circ} 06.703^{\prime}$ & $15^{\circ} 13.307^{\prime}$ & 713 & Upper-slope & 6.32 \\
EG-02 & $75^{\circ} 12.907^{\prime}$ & $13^{\circ} 04.587^{\prime}$ & 1722 & Middle-slope & 3.05 \\
EG-03 & $75^{\circ} 50.615^{\prime}$ & $12^{\circ} 58.353^{\prime}$ & 1432 & Middle-slope & 2.91 \\
\hline
\end{tabular}

$S V$ SVAIS project, EG EGLACOM project 
Table 2 Radiocarbon dates (after Lucchi et al. [58])

\begin{tabular}{|c|c|c|c|c|c|c|c|}
\hline Sample ID & Lab ref. & Sample type & Description & \multicolumn{2}{|c|}{$\mathrm{AMS}^{14} \mathrm{C} \pm$ err. } & $\partial 13 \mathrm{C}$ & cal a $\mathrm{BP} \pm 1 \sigma$ \\
\hline \multicolumn{8}{|l|}{ Upper-slope } \\
\hline SV2-5-39/40 & OS-77655 & Foraminifera & Benthic + planktonic & 15,050 & \pm 50 & -0.24 & $17,748 \pm 139$ \\
\hline SV3-1-0/1 & OS-77656 & Foraminifera & Benthic + planktonic & 4860 & \pm 30 & -0.07 & $5039 \pm 87$ \\
\hline SV3-1-32/33 & OS-82683 & Mollusc & Bivalve & 13,000 & \pm 45 & 1.09 & $14,929 \pm 141$ \\
\hline SV3-6-21/30 & OS-82684 & Forams and ostracods & Benthic + plankt. + ostrac. & 13,200 & \pm 50 & -0.85 & $15,061 \pm 146$ \\
\hline SV3-6-52/53 & OS-77680 & Foraminifera & Benthic + planktonic & 13,300 & \pm 50 & -0.4 & $15,156 \pm 117$ \\
\hline SV5-4-82/83 & OS-82689 & Foraminifera & Mix plankt. mostly Nps & 17,350 & \pm 85 & -0.08 & $20,055 \pm 166$ \\
\hline \multicolumn{8}{|l|}{ Mid-slope } \\
\hline SV4-1-0/1 & OS-77682 & Foraminifera & Nps & 1100 & \pm 25 & 0.44 & $594 \pm 36$ \\
\hline SV4-2-11/12 & OS-77683 & Foraminifera & Nps & 4000 & \pm 30 & 0.83 & $3896 \pm 56$ \\
\hline SV4-2-48/49 & OS-82685 & Foraminifera & Mixed planktonic & 7110 & \pm 30 & 0.5 & $7519 \pm 38$ \\
\hline SV4-2-59/60 & OS-77684 & Foraminifera & Nps & 7880 & \pm 45 & 0.5 & $8264 \pm 59$ \\
\hline SV4-2-65/66 & OS-77685 & Foraminifera & Nps & 8180 & \pm 35 & 0.33 & $8558 \pm 58$ \\
\hline SV4-2-85/86 & OS-82686 & Foraminifera & Mixed planktonic & 8690 & \pm 30 & -0.44 & $9292 \pm 70$ \\
\hline SV4-3-24/27 & OS-82687 & Foraminifera & Bethic + planktonic & 9790 & \pm 30 & 0.64 & $10,558 \pm 33$ \\
\hline SV4-3-77/79 & OS-82688 & Foraminifera & mixed planktonic & 12,050 & \pm 40 & 0.09 & $13,389 \pm 61$ \\
\hline SV4-4-94/95 & OS-77686 & Foraminifera & Nps & 21,800 & \pm 100 & -0.07 & $25,438 \pm 241$ \\
\hline EG2-1-30/31 & OS-78387 & Foraminifera & Bethic + planktonic & 4570 & \pm 130 & -25 & $4665 \pm 164$ \\
\hline EG2-1-90/91 & OS-78389 & Foraminifera & Bethic + planktonic & 9460 & \pm 180 & 0 & $10,235 \pm 234$ \\
\hline EG2-2-60/61 & OS-78383 & Forams and pteropods & Benthic + plankt. + pterop. & 12,100 & \pm 180 & 1.41 & $13,481 \pm 181$ \\
\hline EG3-1-90/91 & OS-78385 & Foraminifera & Bethic + planktonic & 4910 & \pm 120 & -25 & $5118 \pm 161$ \\
\hline EG3-2-56/57 & OS-78382 & Foraminifera & Bethic + planktonic & 8590 & \pm 130 & 0.01 & $9147 \pm 167$ \\
\hline EG3-3-38/39 & OS-78324 & Foraminifera & Bethic + planktonic & 9740 & \pm 80 & 0.73 & $10,508 \pm 87$ \\
\hline
\end{tabular}

Nps Neogloboquadrina pachyderma sin

to the surrounding seafloor and are bound by elongated berms about $500 \mathrm{~m}$ wide and about $10 \mathrm{~m}$ high (Fig. 3). Three or four parallel furrows compose each set of bottom scours. Outer shelf furrows bear two elongation directions: NE-SW that coincides with the main direction of the Storfjorden glacial trough axis, and E-W. Lower resolution Olex bathymetry suggests that NE-SW furrows extend further landwards in water as shallow as $200 \mathrm{~m}$ in the southwestern edge of the Storfjorden glacial trough marking the northwestern flank of Spitsbergenbanken (Figs. 1, 3 ). The largest set of furrows observed is $35 \mathrm{~km}$ long and $1 \mathrm{~km}$ wide (Fig. 3a).

Similar furrows have been identified on many polar continental margins in water depth reaching $1000 \mathrm{~m}$ [25], such as on the Yermak Plateau north of Svalbard [27], offshore West Greenland [49], the Canadian margin [66], in Pine Island Bay, Antarctica [40], and on the Argentine continental margin [55]. They are produced by the seafloor scouring of mega-scale iceberg keels (megabergs, [27, 87]).

These sets of large parallel furrows are not associated to the sets of smaller (4-5 m deep and on average $300 \mathrm{~m}$ wide), $\mathrm{V}$-shaped, linear, subdued ridges and groves, with a mean NE-SW orientation, conformable to the main Storfjorden Trough axis, traceable for up to $20 \mathrm{~km}$ inland (Fig. 3a, b). These sets of large furrows are rather interpreted as Mega Scale Glacial Lineations (MSGL) produced by streaming ice and, like in adjacent Kveithola Trough $[69,72]$, loose their morphological expression near the continental shelf edge due to the presence of moraine banks intensely scoured by icebergs.

The large parallel furrows on the northern flank of Spitsbergen Bank are instead interpreted being produced by large, multi-keel icebergs released during break-off of the Storfjorden sub-ice stream III fed by the Spitsbergenbanken ice cap. Such icebergs were concentrated on the southeaster part of the Storfjorden Trough because the source of continental ice for this sub-ice stream was closes the continental shelf break $[64,58])$.

\section{Sediment geochemistry and composition}

The characteristics for the sediments facies observed in the upper and middle slope are very much consistent. For this reason, in the following we will show only the down-core 


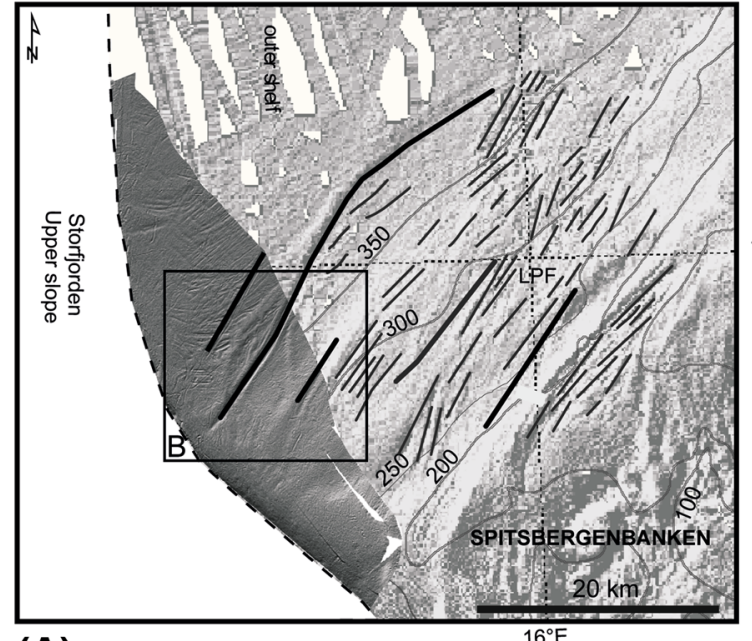

(A)

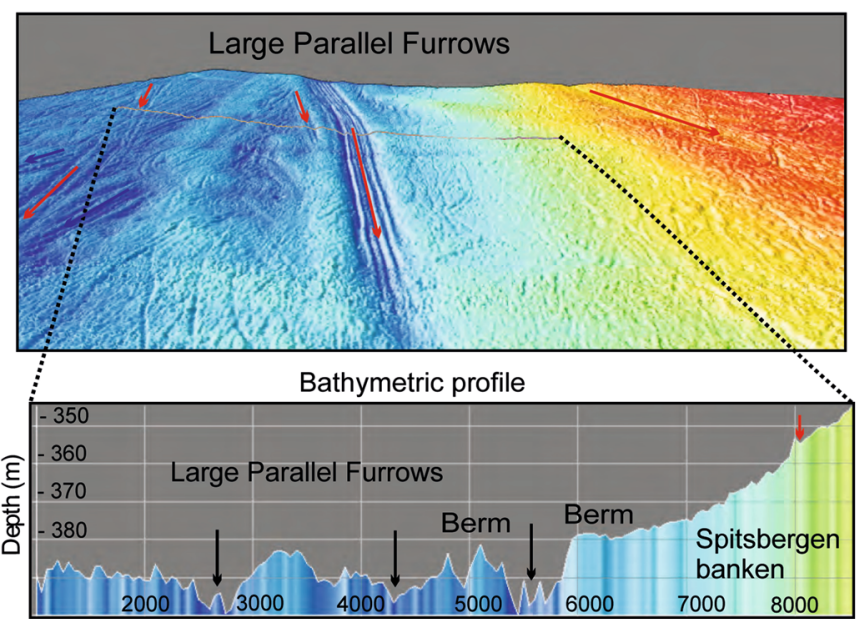

(C)

Fig. 3 Seabed morphology evidence of multi-keel mega-icebergs scours. a SVAIS-EGLACOM bathymetry superimposed to the Olex Ocean DTM ${ }^{\circledR}$ outlining the regional extent of the furrows beyond the SVAIS-EGLACOM bathymetric coverage. Large parallel furrows are

sedimentological characteristics of cores SV-02 and SV-04 as the most representative for the upper and middle slope, respectively (Fig. 4).

Core SV-02 is characterized by a high $\mathrm{C}_{\text {org }} / \mathrm{N}_{\text {tot }}$ ratio always largely exceeding the boundary value of 10 (except for the interval above the oxidized layer) indicating predominant continental-derived organic matter input. The smectite content in the sediments located above the glacigenic diamicton increases gradually up-core, whereas it is virtually absent in the LGM sediments.

The Si content is generally high throughout the core but decrease in the upper $25 \mathrm{~cm}$ (distal glacimarine sediments). Lower values are observed also between the oxidized layer and the interval characterized by the presence of marinederived organic matter (388-400 cm bsf). The down-core

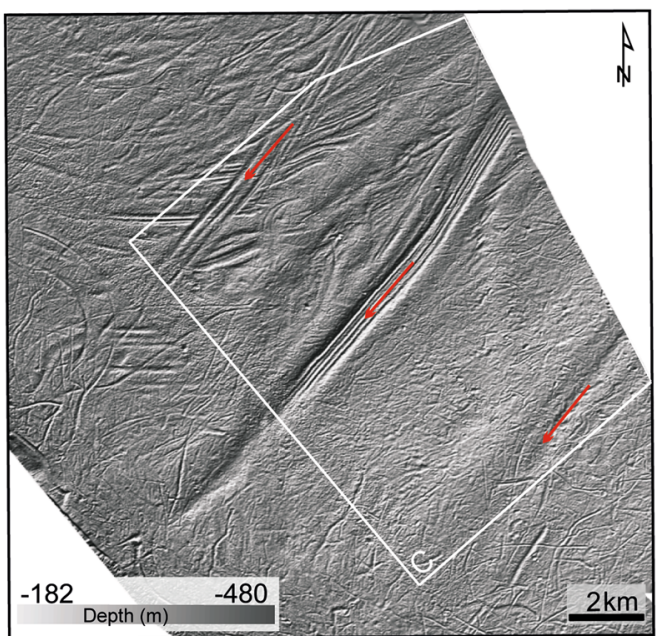

(B)

\section{Large parallel furrows $V$-shaped linear ridges and grooves}

Shelf break
Mega-icebergs direction
Contour $(50 \mathrm{~m})$

outlined by thick black lines; b DETAILED bathymetry (SVAISEGLACOM data sets) of multi-keel mega-icebergs scours. c 3D view and topographic profile across the multi-keel mega-icebergs scours

trend of $\mathrm{Cl}$ distribution is in agreement with the water content measured on individual samples with $\mathrm{Cl}$ peaks corresponding to the sandy layers in the interlaminated sediments. The boundary between LGM sediments and the proximal glacimarine sediments is characterized by a salient change in $\mathrm{Cl}$ content. This boundary is also characterized by abrupt changes in the other parameters including the $\mathrm{S}$ content with high values within LGM sediments that contain partially pyritized carbonate rock fragments with framboid pyrite.

Core SV-04 is characterized by predominant marinederived organic matter input except for the proximal glacimarine sedimentation (massive IRD input) and the interlaminated sediment facies. The trend of smectite content is characterized by a progressive increase from the 


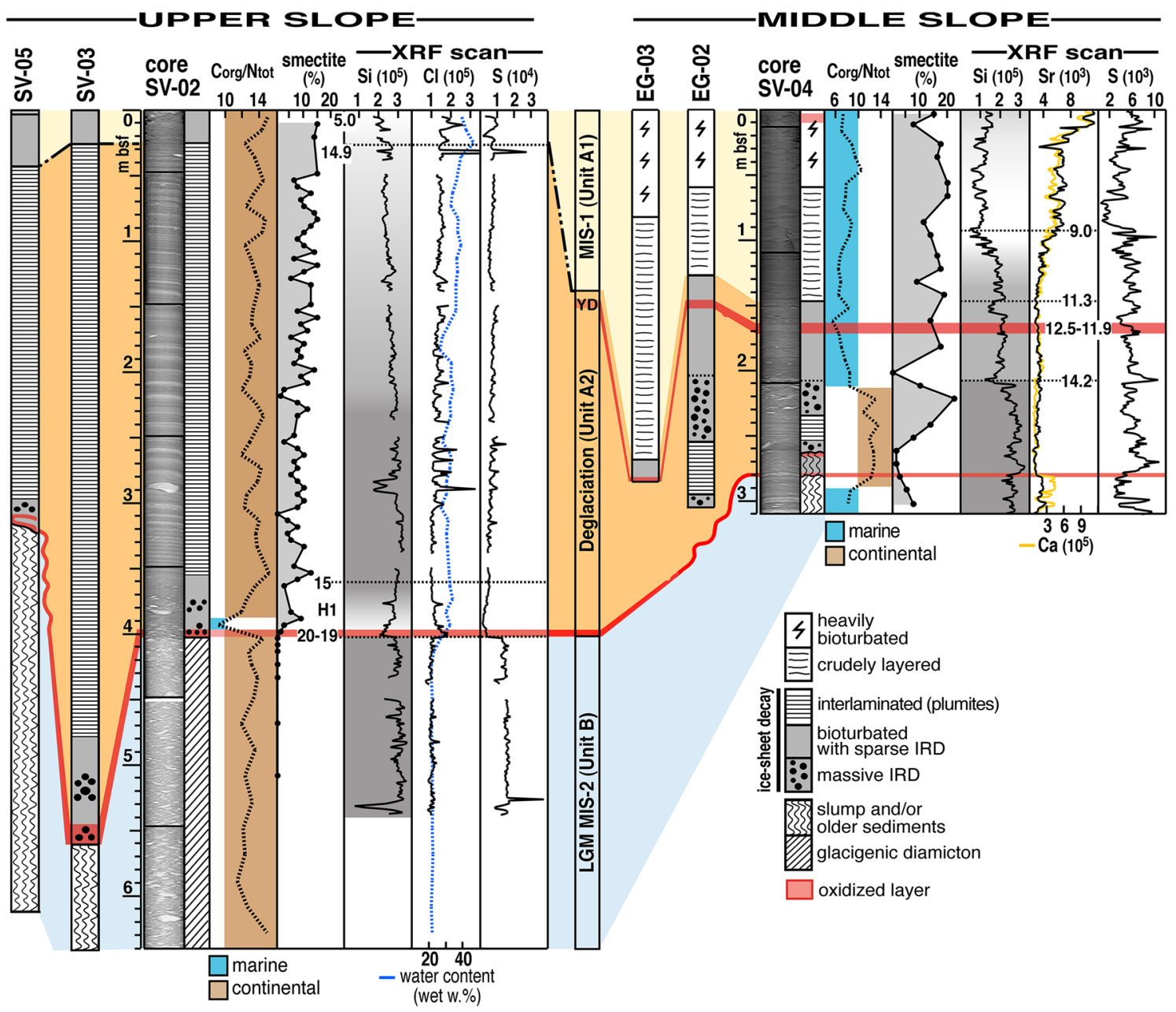

Fig. 4 Down-core distribution of sedimentological and compositional parameters measured in the studied cores. The depositional significance of the synthetic lithological $\log$ is explained in Fig. 2.

base of post-LGM deposition $(260 \mathrm{~cm} \mathrm{bsf})$, to the beginning of the distal glacimarine sedimentation (ca $200 \mathrm{~cm} \mathrm{bsf}$ ) after which the values are maintained stables with only minor fluctuations (minimum value at $202 \mathrm{~cm}$ bsf can be related to local sampling of IRD). The trend of Si content presents three main steps: the glacial, proximal glacimarine and interlaminated sediments have the higher Si content, whereas minor values characterize the distal glacimarine sedimentation. In the upper part of the core, the $\mathrm{Si}$ content decreases within the crudely layered sediments and became almost stable after about 9 cal ka BP. The Sr content is very low in the proximal glacimarine and interlaminated sediments with only slightly higher values in the distal glacimarine sediments. On the contrary, the Sr content increases considerably in the upper part of the core within the heavily bioturbated sediments having a trend very similar to that of Ca content. The $\mathrm{S}$ content is generally high within the
Black bold numbers on the down-core logs refer to ages (cal ka BP) according to the age model of Sagnotti et al. [73] and Lucchi et al. [58]. Seismic Units A1, A2, B according to Pedrosa et al. [64]

glacimarine and interlaminated facies as well as the older interval of the crudely layered sediments. A sharp decrease of $S$ values occurs at around 9 cal ka BP after which the values increases again towards the top of the core. The $\mathrm{S}$ content in the middle slope cores is, however, one-order of magnitude lower than the one measured in the upper slope cores.

\section{Sediment palaeomagnetic properties}

The geomagnetic angular dispersion related to Palaeosecular Variations (PSV) should increase with latitude [21, 60, 23]. At fixed latitudes (i.e., at a core site), the sampled time interval is another factor affecting the measured Virtual Geomagnetic Pole (VGP) dispersion. In general, samples spanning a temporally large interval (e.g., $>10 \mathrm{ka}$ ) that fully sample the geomagnetic PSV define a large scatter of 
the measured VGPs, whereas samples referring to temporally short events under-represent the geomagnetic PSV resulting in a limited VGP scatter $(S)$.

Within the interlaminated sediments, the VGP scatter computed from characteristic remnant magnetization directions of SV-02 is very limited, with an $S$ value of $9.3^{\circ}$ (Fig. 5a), whereas in core SV-03 the $S$ value is as low as $8.5^{\circ}$ (Fig. $5 \mathrm{~b}$ ). The VGP scatter in the interlaminated sediments of core SV-05 is, instead, as large as $15.8^{\circ}$ (Fig. 5c).

In core SV-04, spanning about the last $18 \mathrm{cal} \mathrm{ka} \mathrm{BP}$ (or up to $25 \mathrm{cal} \mathrm{ka} \mathrm{BP}$, considering the possibly reworked sediments at the bottom of the core), the VGP scatter is rather large, with an $S$ value of $17^{\circ}$ (Fig. 5d), that is comparable with the VGP scatter determined for core EG$02\left(16.9^{\circ}\right.$, Fig. 5e), spanning a slightly shorter time (last $16 \mathrm{cal}$ ka BP). In core EG-03, that contains an expanded Holocene sequence containing the record of the Younger Dryas (YD) at its base, the VGP scatter is relatively small (12.1 ${ }^{\circ}$, Fig. 5f) with respect to core SV-04 and EG-02, but still much higher than the values determined for the plumites of cores SV-02 and SV-03.

\section{Discussion}

\section{The NW Barents Sea sedimentary record of MWP-1a}

The over 4.5 meter thick interlaminated plumites derived from meltwater discharge from the Storfjorden-Kveithola glacial system, was deposited in about 130 years at a very high sedimentation rate of $3.4 \mathrm{~cm} \mathrm{a}^{-1}$, at about $7 \mathrm{~km}$ from the present shelf break. This sedimentary signature has been correlated to the MWP-1a event by Lucchi et al. [58] based on sedimentological, geochemical and chronostratigraphic analysis.

Initial uncertainties on the stratigraphic assignment of such deposit were related to (a) the slightly older ages determined in core SV-03 $(15,061 \pm 146-14,929 \pm 141$ cal a BP), with respect to the establish timing for the meltwater event $(14,650-14,310 \mathrm{cal}$ a BP, [24]), and (b) the age range assigned to the plumites (about 130 a) that is comparable with the calibrated age error $( \pm 143$ a).

The slightly older ages of the Storfjorden-Kveithola upper slope plumites can be explained with an
Fig. 5 Distribution of the Virtual Geomagnetic Pole (VGP) within the interlaminated sediments (yellow area) of cores a SV-02, b SV-03, c SV-05, and within the whole sedimentary sequence of cores d SV-04 (last 18 cal ka BP), e EG-02 (last 16 cal ka BP), and $\mathbf{f}$ EG-03 (last 12 cal ka BP). $S=$ VGP scatter

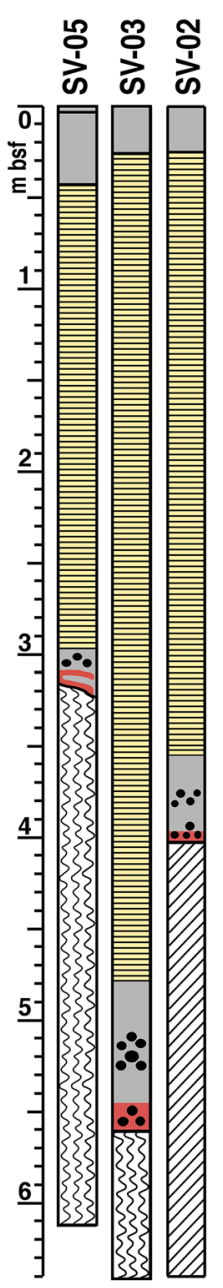

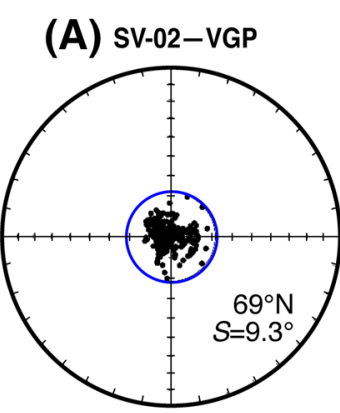

(B) SV-03-VGP

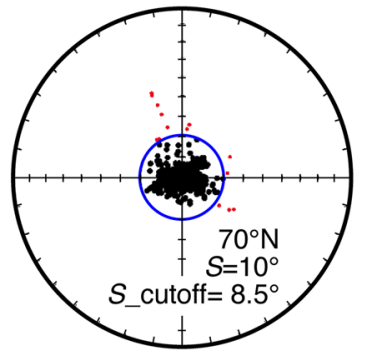

(C) SV-05-VGP

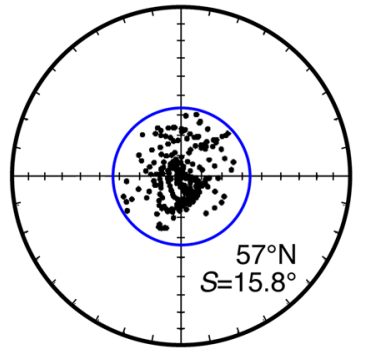

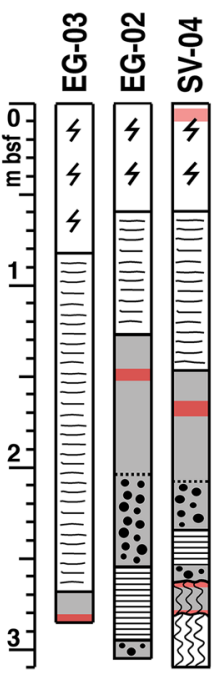

(D) SV-04-VGP

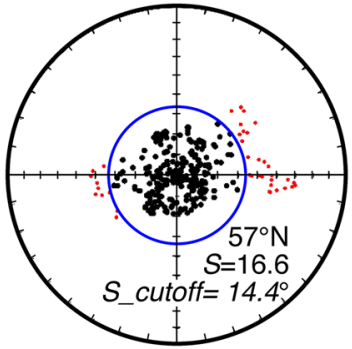

(E) EG-02-VGP

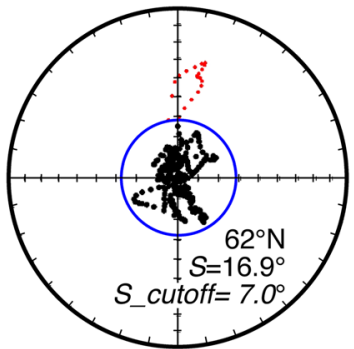

(F) EG-03-VGP

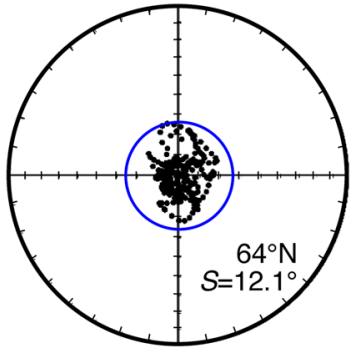


underestimation of the local regional reservoir correction applied to the radiocarbon calibration of mixed benthic and planktonic foraminifera. Sarnthein [75], Rae et al. [67], and Thornalley et al. [84], indicated that deep ocean waters after the LGM and during deglaciation were up to 1-2 ka older than they are today determining a higher local reservoir age. In our case the aging effect of the benthic and planktonic foraminifera mix to explain the correlation to the MWP-1a is only 400-600 a.

The plumites recorded in the SVAIS-EGLACOM cores are constrained by an excellent palaeomagnetic and stratigraphic correlation with the sedimentary sequences described west of Svalbard and neighboring glacial depositional systems [42] where radiocarbon ages align with the timing of MWP-1a as defined in tropical areas.

Stratigraphic equivalent deposits have been reported from other areas offshore the West and North Svalbard margin including the Yermak Plateau [7, 13, 28, 42, 68, 72], and the southern Barents Sea [88], indicating a nearly synchronous regional event responsible for a massive sediment input likely accompanied by a huge flux of fresh meltwater into the northern Atlantic and Arctic Oceans.

The rapid emplacement of the interlaminated plumites is supported beyond the radiocarbon dating by sediments palaeomagnetic characteristics. According to various models of geomagnetic Palaeosecular Variation (e.g., [23, $60,83]$ ), the Virtual Geomagnetic Pole (VGP) scatter representing the full geomagnetic Palaeosecular Variation (PSV) spectrum of variability at the geographic latitudes of the sampled cores, should be between $15^{\circ}$ and $20^{\circ}$. At fixed latitude (i.e., at a core site), the sampled time interval is another factor affecting the retrieved VGP dispersion. In general, samples spanning a temporally large interval (e.g., $>10 \mathrm{ka}$ ) fully sample geomagnetic PSV and provide a reliable estimate of the VGP scatter, whereas samples referring to temporally short events under-represent geomagnetic PSV resulting in a limited VGP scatter. The very low VGP scatter measured in the interlaminated sediments of cores SV-02 and SV-03 indicates that this stratigraphic interval spans a time period that is not long enough to fully represent the overall spectrum of variability of geomagnetic PSV, notwithstanding a thickness of 3-4 m (Fig. 6). This inference is consistent with the very high sedimentation rate indicated by radiocarbon dating. The higher values measured in the plumite record of core SV-05, located at the head-scar of a landslide, were related to minor synsedimentary re-depositional events occurred during the plumites emplacement Sagnotti et al. [74].

The plumite layer is easily tracked on in the sub-bottom profiler record of the $300 \mathrm{~km}$ long Storfjorden-Kveithola margin. The thickness is estimated, using a $1500 \mathrm{~m} \mathrm{~s}^{-1}$ average sound velocity in such water-rich sediments, to be over $20 \mathrm{~m}$-thick in the SE end of the Storfjorden TMF. The

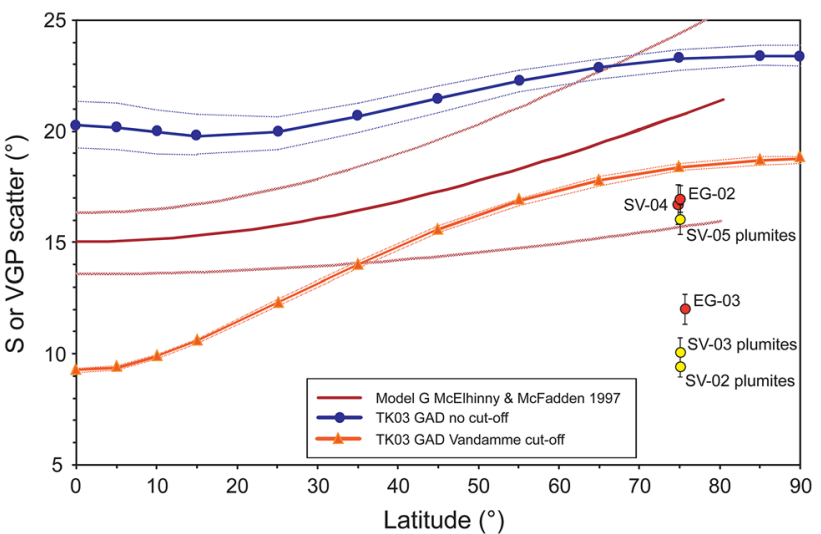

Fig. 6 Models of VGP scatter values $(S)$ with respect to geographic latitude according to Vandamme [86], McElhinny and McFadden [59], Tauxe and Kent [83]. Yellow circles indicate the $S$ values from the plumite interval of cores SV-02, SV-03 and SV-05, whereas red circles indicate the $S$ values for the sedimentary sequence of cores SV-04, EG-02, and EG-03

thickness decreases rapidly down-slope where it becomes negligible at about $35-40 \mathrm{~km}$ form the present shelf break in about $1800 \mathrm{~m}$ water depth. The NW end of the Storfjorden TMF is characterized by a thinner plumite sequence due to faster withdrawal of the ice stream in that area [58].

The extent of the deglaciation seismic Unit A was mapped on the Storfjorden-Kveithola TMFs and the decompacted sedimentation rate averaged over $19.5 \mathrm{ka}$ was calculated to be $0.6 \mathrm{~kg} \mathrm{~m}^{-2} \mathrm{a}^{-1}$ [54]. If we scale these values to the MWP-1a depositional event, volumetrically forming about $90 \%$ of seismic Unit A, and considering a duration of about 130 years, as measured in our cores, the sediment mass accumulation rate results as high as $78 \mathrm{~kg} \mathrm{~m}^{-2} \mathrm{a}^{-1}$, corresponding to a total sediment mass accumulation of $1.1 \times 10^{11}$ tonnes on the upper continental slope.

These values further stress the extreme nature of the MWP-1a sedimentary event recorded on the upper slope of Storfjorden-Kveithola TMFs.

\section{Forcing mechanisms and environmental conditions during MWP-19 ka and MWP-1a}

The presence of clustered glacigenic debrites forming the TMF of the North-western Barents Sea continental margin confirms fully glaciated conditions of the shelf area during the LGM [2, 50, 64]. Dating of these deposits indicate the grounded ice streams reached the shelf edges at ca. 24 cal ka BP ([26, 42], Fig. 7a).

There is a large consensus on considering enhanced summer insulation as the primary mechanism determining the onset of the northern hemisphere deglaciation. Intense 
ice-melting from the northern hemisphere ice sheets and mountain glaciers produced a large volume of meltwaters with deposition of a several $\mathrm{m}$-thick laminated sequence on the northern continental margins (e.g., [36, 37, 52, 85]). This event produced a first abrupt global sea-level rise (MWP-19 ka) and a renewal of the Atlantic Meridional Overturning Circulation [15, 19, 34].

The oxidized and massive IRD layer overlying LGM sediments in the SVAIS-EGLACOM cores, records the Storfjorden ice stream response to MWP-19 ka responsible for breakdown of the outer part of the grounded ice shelf (Fig. 7b). Oxidized sediments, characterized by low sulfur content, presence of planktonic foraminifera, and marinederived organic matter indicate deep ocean ventilation with

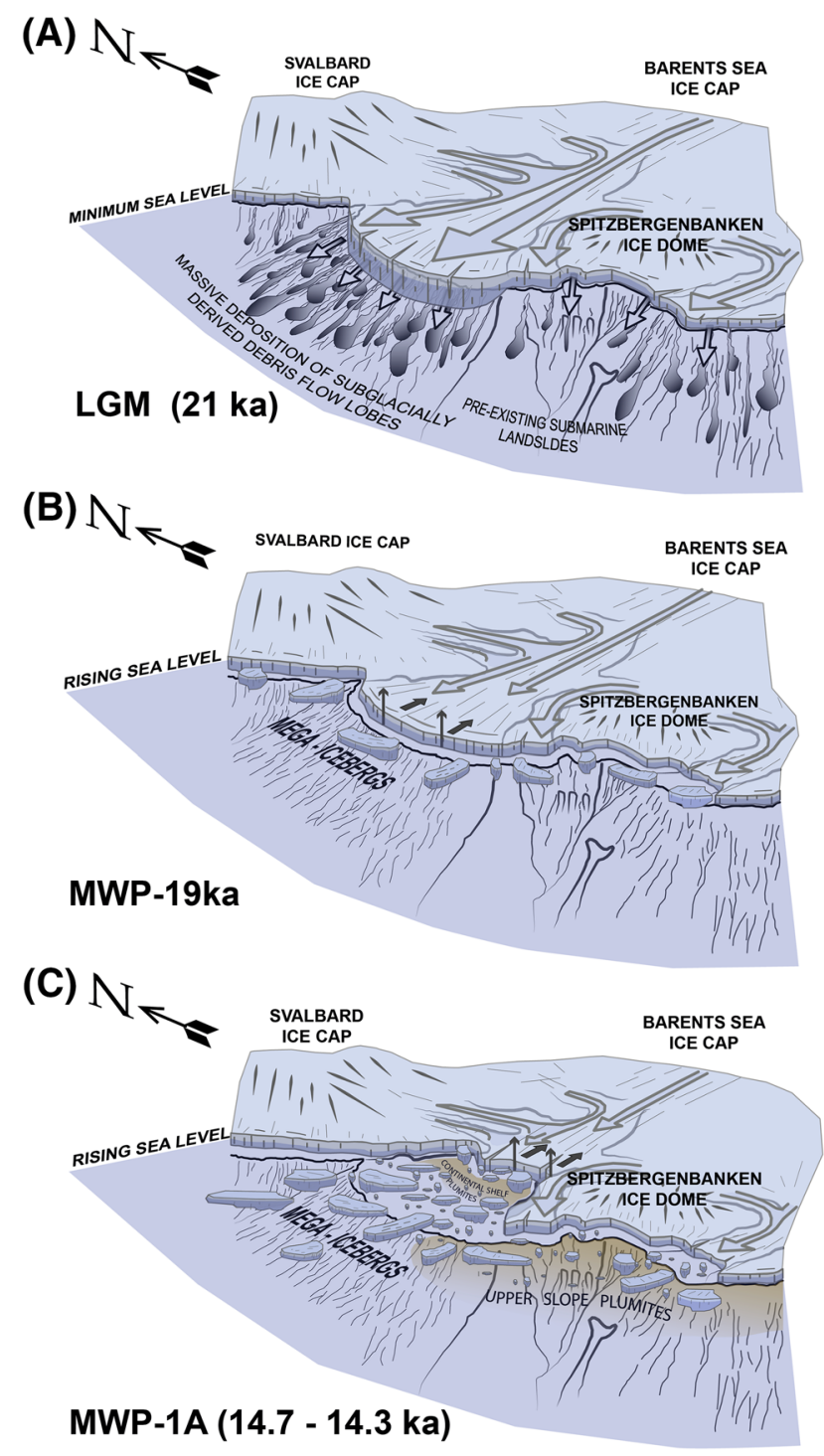

Fig. 7 Schematic graphic representation of the three main depositional events recording the Storfjorden and Kveithola ice stream dynamics in the SVAIS-EGLACOM sediment cores. a LGM, b inception of ice stream decay during MWP-19 ka; c ice stream collapse during/after MWP-1a ice-free (or seasonal) surface conditions. These environmental characteristics support the re-establishment of a vigorous thermohaline circulation in the north Atlantic after the LGM.

According to Llopart et al. [53], the rapid sea-level rise during MWP-19 ka was also responsible for local slope instability due to destabilized distribution of slope interstitial pore pressure along the Storfjorden-Kveithola TMFs, due to the rapid increase of sea-hydrostatic pressure (slump/debrites involving, or among, the oxidized layer in cores SV-05 and SV-04).

Detachment and lift-off of the marine-based grounded ice streams on the deep Antarctic shelves of the Southeastern Weddell Sea, Antarctic Peninsula and Amundsen Sea in response to sea-level forcing during MWP-19 ka, lead to the deposition of a thick laminated sequence underneath the Antarctic ice shelves [35, 90, 91]. Antarctic meltwater release was in turn responsible for (1) a further strengthening of the Atlantic meridional overturning circulation accelerating the climate warming of the North Atlantic region (onset of the Bølling-Allerød warm interval, [89]) and (2) promoted sea-level rise forcing lift-off of shallow marine grounded ice streams including the Storfjorden and Kveithola ice streams in the northern margins. Evidence of renewed North Atlantic warm inflows at the onset of the Bølling warm interval were reported in the south Svalbard [42, 68], west and northern Svalbard margins [13, 14, 46, 79, 80], the Franz Victoria Trough [48, 56] and the NW Yermak slope [7].

Ice shelves are more sensitive to warm sub-glacial inflows forcing their rapid melting and retreat [76]. Reenhanced warm North Atlantic inflows were responsible for fast decay of the Storfjorden and Kveithola ice streams with extensive ice-melting and retreat to an inner grounding line, contributing significantly to global sea-level rise during MWP-1a (Fig. 7c).

Contemporaneous intense calving from the retreating ice stream in the Storfjorden Trough is inferred to have generated the release of multi-keel megabergs responsible for the mega-scours visible on the Storfjorden outer continental shelf in water depth as deep as $390 \mathrm{~m}$ below presentday sea level. The chronology of this event fits well with the modeled 15,000 ka peak flux of iceberg across the Storfjorden Trough [77].

Melting of the main Storfjorden ice streams (I and II) occurred with a rapid retreat to the shallower grounding zone wedges located on the middle shelf (thinner plumites on the slope facing lobe I and II, Fig. 1). Diffuse melting and rapid retreat in this area was likely responsible for a thinner ice shelf, producing thinner icebergs unable of deep scouring the seafloor. On the contrary, the Kveithola and the south-western Storfjorden ice stream III, were probably active longer as they were fed by a closer ice catchment 
area (Spitsbergenbanken ice cap), producing a larger sequence of plumites on the continental slope facing lobe III and the Kveithola Trough.

The high sulfur content measured in the Storfjorden interlaminated sediments indicates reduced sea bottom ventilation likely caused by strong water stratification under extensive fresh water release during MWP-1a. It is also possible that the presence of surface fresh water enhanced multi-year sea ice formation during the plumite deposition that would explain the little occurrence of IRD within the interlaminated sediments. Strong water stratification would contribute to reduce nutrient availability hampering the bio-productivity and to promote poor deepwater ventilation affecting the preservation of calcareous foraminifera tests in the sediments, already diluted by the strong detrital input (barren sediments).

In addition, surface water stratification would enhance the areal distribution and sediment dispersion of the meltwater plumes by reducing sediment flocculation in the fresh water and particle settling across the halocline surface (c.f. $[36,57])$. This explains the wide spread occurrence of fine-grained laminated sediments having considerable thickness only on the upper slope of TMFs in the area close to the sediment source output.

The interlaminated plumite sequence is sharply topped by a massive IRD layer that records the collapse of the outer part of the Storfjorden and Kveithola ice shelves (ca 14.2 cal ka BP, [8, 72]). The abrupt disappearance of the main TMFs source of terrigenous input is responsible for a strong change in the sedimentation rate with starving TMFs receiving sediments only through icebergs, wind, and along-slope contour currents (sharp decrease in Si content at $14.3 \mathrm{cal} \mathrm{ka} \mathrm{BP,} \mathrm{Fig.} \mathrm{4).} \mathrm{The} \mathrm{sediment} \mathrm{composition}$ changes rapidly with increasing content of smectite and a swift change in organic matter composition being of marine origin $\left(\mathrm{C}_{\text {org }} / \mathrm{N}_{\text {tot }}\right.$ ratio $\left.<10\right)$. We think that the abrupt "switch-on" of the thermohaline circulation described to occur after melt water pulses went together with the "shutdown" of the sediment discharge and starving of TMFs affecting the Svalbard margins [13, 42, 78], the northern Barents Sea (Franz Victoria Trough, [48]) and part of the Arctic Ocean (NW Yermak slope, [7]) suggesting a major sudden decay of the ice sheet in the NW Barents Sea.

\section{Conclusions}

Decay and retreat of the Storfjorden and Kveithola palaeoice streams after the LGM were reconstructed through sedimentological and geochemical analysis of deep-sea marine sediments and new multi-beam and sub-bottom profiler data analysis.
The sedimentary record on the upper continental slope contains a several m-thick sequence of plumites deposited under an extensive meltwater event associated to the palaeo-ice streams decay. Radiometric dating and rock palaeomagnetic characteristics indicate a very fast event (ca. 130 years) responsible for the settling of about $1.1 \times 10^{11}$ tonnes of sediments on the upper slope of the Storfjorden-Kveithola TMFs with an extreme sedimentation rate of $3.4 \mathrm{~cm} \mathrm{a}^{-1}$. New data constrains confirm an early interpretation that related the event to the Meltwater Pulse 1-a.

New sedimentological and geochemical insights indicate that strong seawater stratification during extensive meltwater release promoted a wide dispersion of finegrained sediments over the continental margin. Consistent thicknesses of the plumites are recorded only on the upper slope of TMFs, close to the sediment source output when the Storfjorden and Kveithola ice streams were grounded at the continental shelf brake during LGM. This would explain the difficulties encountered to find a substantial "MWP-1a deposit" in different settings of the Arctic, as well as Antarctic, areas.

A major ice sheet collapse at the end, or during, the MWP-1a produced multi-keel megabergs scouring the outer Storfjorden continental shelf, followed by TMFs sediment starving that signed the reprise of the biogenic activity and strengthening of the Termohaline Circulation (THC). The whole sequence of THC "swich on"-extreme short-term accumulation of fine sediments with apparent THC "shut-down"-restart of the THC and reduction of sediment delivery to the slope, described offshore the Storfjorden-Kveithola glacial troughs, was observed in many other areas of the NW Barents Sea and NW Yermak slope, suggesting the whole margin underwent an almost synchronous depositional fate with a major sudden decay of the ice sheet after, or during, the MWP-1a event.

Acknowledgments This study was supported by the Spanish IPY projects SVAIS (POL2006-07390/CGL) NICE STREAMS Spain (CTM2009-06370-E/ANT), and DEGLABAR (CTM2010-17386), the Italian projects OGS-EGLACOM, and PNRA-CORIBAR (PdR 2013/C2.01). We thank ENI E\&P Division (Milan, Italy) for the analysis with the X-ray CT scan, and the scientific teams of SVAIS, EGLACOM and CORIBAR projects. We are grateful to Henning Bauch, Christian Hass and another anonymous reviewer for comments and suggestions that greatly improved the manuscript.

Open Access This article is distributed under the terms of the Creative Commons Attribution 4.0 International License (http://crea tivecommons.org/licenses/by/4.0/), which permits unrestricted use, distribution, and reproduction in any medium, provided you give appropriate credit to the original author(s) and the source, provide a link to the Creative Commons license, and indicate if changes were made. 


\section{References}

1. Alley RB, Clack PU, Huybrechts P, Jounghin I (2005) Ice-sheet and sea-level changes. Science 310:456-460

2. Andreassen K, Nilssen LC, Rafaelsen B, Kuilman L (2004) Three-dimensional seismic data from the Barents Sea margin reveal evidence of past ice streams and their dynamics. Geology 32(8):729. doi:10.1130/G20497.1

3. Bard E, Hamelin B, Arnold M, Montaggioni L, Cabioch G, Faure G, Rougerie F (1996) Deglacial sea-level record from Tahiti corals and the timing of global meltwater discharge. Nature 382:241-244

4. Bard E, Hamelin B, Delanghe-Sabatier D (2010) Deglacial Meltwater Pulse 1B and Younger Dryas Sea Levels Revisited with Boreholes at Tahiti. Science 327:1235-1237

5. Bentley MJ, Fogwill CJ, Le Brocq AM, Hubbard AL, Sugden DE, Dunai TJ, Freeman S (2010) Deglacial history of the West Antarctic Ice Sheet in the Weddell Sea embayment: constraints on past ice volume change. Geology 38:411-414

6. Bentley MJ, O'Cofaigh C, Anderson JB et al (2014) A community-based geological reconstruction of Antarctic Ice Sheet deglaciation since the Last Glacial Maximum. Quat Sci Rev 100:1-9. doi:10.1016/j.quascirev.2014.06.025

7. Birgel D, Hass HC (2004) Oceanic and atmospheric variations during the last deglaciation in the Fram Strait (Arctic Ocean): a coupled high-resolution organic-geochemical and sedimentological study. Quat Sci Rev 23:29-47

8. Bjarnadóttir LR, Rüther DC, Winsborrow MCM, Andreassen K (2013) Grounding-line dynamics during the last deglaciation of Kveithola, W Barents Sea, as revealed by seabed geomorphology and shallow seismic stratigraphy. Boreas 42:84-107

9. Blanchon P (2011) Meltwater pulses. In: Hopley David (ed) Encyclopedia of Modern Coral Reefs: Structure, form and process. Springer, Encyclopedia of earth science series, pp 683-690

10. Blanchon P, Shaw J (1995) Reef drowning during the last deglaciation: evidence for catastrophic sea-level rise and icesheet collapse. Geology 23:4-8

11. Blanchon P, Jones B, Ford DC (2002) Discovery of a submerged relic reef and shoreline off Grand Cayman: further support for an early Holocene jump in sea level. Sediment Geol 147:253-270

12. Camerlenghi A, Rebesco M, Accettella D (2015) Trough-mouth fan, Storfjorden. In: Dowdeswell JA, Canals M, Jakobsson M, Todd BJ, Dowdeswell EK, Hogan KA (eds) Atlas of Submarine Glacial Landforms, Mem Geol Soc London (in press)

13. Chauhan T, Rasmussen TL, Noormets R (2015) Palaeoceanography of the Barents Sea continental margin, north of Nordaustlandet, Svalbard, during the last $74 \mathrm{ka}$. Boreas. doi:10.1111/bor. 12135

14. Chauhan T, Rasmussen TL, Noormets R, Jakobsson M, Hogan KA (2014) Glacial history and paleoceanography of the southern Yermak Plateau since $132 \mathrm{ka}$ BP. Quat Sci Rev 92:155-169. doi:10.1016/j.quascirev.2013.10.023

15. Clark PU, McCabe AM, Mix AC, Weaver AJ (2004) Rapid rise of sea level 19,000 years ago and its global implications. Science 304:1141-1144

16. Clark PU, Alley RB, Keigwin LD, Licciardi JM, Johnsen SJ, Wang H (1996) Origin of the first global meltwater pulse following the Last Glacial Maximum. Paleoceanography 11:563-577

17. Clark PU, Arthur SD, Shakun JD, Carlson AE, Clark J, Wohlfarth B, Mitrovica JX, Hostetler SW, McCabe AM (2009) The Last Glacial Maximum. Science 325:710-714

18. Clark PU, Mitrovica JX, Milne GA, Tamisiea ME (2002) Sea level finger printing as a direct test for the source of global meltwater pulse 1a. Science 295:2438-2441
19. Clark PU, Pisias NG, Stocker TF, Weaver AJ (2002) The role of the thermohaline circulation in abrupt climate change. Nature 415:863-869

20. Clark PU, Shakun JD, Baker PA et al (2012) Global climate evolution during the last deglaciation. P Natl Acad Sci USA 109(19):E1134-E1142

21. Cox A (1970) Latitude dependence of the angular dispersion of the geomagnetic field. Geophys J Roy Astr S 20:253-269

22. Crucifix M, Berger A (2002) Simulation of ocean-ice sheet interactions during the last deglaciation. Paleoceanography 17(4): 1054

23. Deenen $\mathrm{MH}$, Langereis $\mathrm{CG}$, van Hinsbergen DJ, Biggin AJ (2011) Geomagnetic secular variation and the statistics of palaeomagnetic directions. Geophys J Int 186(2):509-520

24. Deschamps P, Durand N, Bard E, Hamelin B, Camoin G, Thomas AL, Henderson GM, Okuno J, Yokoyama Y (2012) Ice-sheet collapse and sea-level rise at the Bølling warming 14,600 years ago. Nature 483:559-564

25. Dowdeswell JA, Bamber JL (2007) Keel depths of modern Antarctic icebergs and implications for sea-floor scouring in the geological record. Mar Geol 243:120-131

26. Dowdeswell JA, Elverhøi A (2002) The timing of initiation of fast-flowing ice streams during a glacial cycle inferred from glacimarine sedimentation. Mar Geol 188(1-2):3-14

27. Dowdeswell JA, Jakobsson M, Hogan KA, O'Regan M, Backmanb J, Evans J, Hell B, Löwemark L, Marcussen C, Noormets R, Cofaigh CÓ, Sellén E, Sölvsten M (2010) High-resolution geophysical observations of the Yermak Plateau and northern Svalbard margin: implications for ice-sheet grounding and deepkeeled icebergs. Quat Sci Rev 29:3518-3531

28. Elverhøi A, Andersen ES, Dokken T, Hebbeln D, Spielhagen R, Svendsen JI, Sørflaten M, Rørnes A, Hald M, Forsberg CF (1995) The growth and decay of the Late Weichselian ice sheet in western Svalbard and adjacent areas based on provenance studies of marine sediments. Quat Res 44:303-316

29. Fairbanks RG (1989) A 17.000-year glacio-eustatic sea level record: influence of glacial melting rates on the Younger Dryas event and deep-ocean circulation. Nature 342:637-642

30. Golledge NR, Menviel L, Carter L, Fogwill CJ, England MH, Cortese G, Levy RH (2014) Nat Comm 5:5107. doi:10.1038/ ncomms6107

31. Gregoire LJ, Payne AJ, Valdes PJ (2012) Deglacial rapid sea level rises caused by ice-sheet saddle collapses. Nature 487:219-222

32. Hanebuth T, Stattegger K, Grootes PM (2000) Rapid flooding of the Sunda Shelf: a late-glacial sea-level record. Science 288:1033-1035

33. Harris PT, Heap AD, Marshall JF, McCulloch M (2008) A new coral reef province in the Gulf of Carpentaria, Australia: colonisation, growth and submergence during the early Holocene. Mar Geol 251:85-97

34. He F, Shakun JD, Clark PU, Carlson AE, Liu Z, Otto-Bliesner BL, Kutzbach JE (2013) Northern Hemisphere forcing of Southern Hemisphere climate during the last deglaciation. Nature 494:81-85

35. Heroy DC, Anderson JB (2007) Radiocarbon constraints on Antarctic Peninsula Ice Sheet retreat following the Last Glacial Maximum (LGM). Quat Sci Rev 26:3286-3297

36. Hesse R, Khodabakhsh S, Klauck I, Ryan WBF (1997) Asymmetrical turbid surface plume deposition near ice-outlets of the PleistoceneLaurentide ice sheet in the Labrador Sea. Geo-Mar Lett 17:179-187

37. Hesse R, Klauck I, Khodabakhsh S, Piper D (1999) Continental slope sedimentation adjacent to an ice margin. III. The upper Labrador Slope. Mar Geol 155:249-276 
38. Hjelstuen BO, Elverhøi A, Faleide JI (1996) Cenozoic erosion and sedimentary yield in the dranaige area of the Storfjorden Fan. Global Planet Change 12:95-116

39. Hjelstuen BO, Sejrup HP, Haflidason H, Nygård A, Ceramicola S, Bryn P (2005) Late Cenozoic glacial history and evolution of the Storegga Slide area and adjacent slide flank regions, Norwegian continental margin. Mar Petrol Geol 22:57-69

40. Jakobsson M, Anderson JB, Nitsche FO et al (2011) Geological record of ice shelf break-up and grounding line retreat. Geology, Pine Island Bay. doi:10.1130/G32153.1

41. Jakobsson M, Mayer L, Coakley B et al (2012) The international bathymetric chart of the Arctic ocean (IBCAO) version 3.0. Geophys Res Lett 39:L12609

42. Jessen SP, Rasmussen TL, Nielsen T, Solheim A (2010) A new Late Weischselian and Holocene marine chronology for the western Svalbard slope 30,000-0 cal years BP. Quat Sci Rev 29:1301-1312

43. Junttila J, Aagaard-Sørensen S, Husum K, Hald M (2010) Late Glacial-Holocene clay minerals elucidating glacial history in the SW Barren Sea. Mar Geol 276:71-85

44. Kirschvink JL (1980) The least-squares line and plane and the analysis of palaeomagnetic data. Geophys J Int 62:699-718

45. Knies J, Matthiesson J, Vogt C, Laberg JS, Hjelstuen BO, Smelror M, Larsen E, Andreassen K, Eidvin T, Vorren TO (2009) The Pliocene glaciation of the Barents Sea-Svalbard region: a new model based on revised chronostragigraphy. Quat Sci Rev 28:812-829

46. Koç N, Klitgaard-Kristensen D, Hasle K, Forsberg CF, Solheim A (2002) Late glacial palaeoceanography of Hinlopen Strait, northern Svalbard. Polar Res 21:307-314

47. Kopp RE (2012) Tahitian record suggests Antarctic collapse. Nature 483:549-550

48. Kleiber H, Knies J, Niessen F (2000) The Late Weichselian glaciation of the Franz Victoria Trough, northern Barents Sea: ice sheet extent and timing. Mar Geol 168:25-44

49. Kuijpers A, Dalhoff F, Brandt MP, Hümbs P, Schott T, Zotova A (2008) Giant iceberg plow marks at more than $1 \mathrm{~km}$ water depth offshore West Greenland. Mar Geol 246:60-64

50. Laberg JS, Vorren TO (1995) Late Weichselian submarine debris flow deposits on the Bear Island Trough Mouth Fan. Mar Geol 127:45-72

51. Laberg JS, Vorren TO (1996) The glacier-fed fan at the mouth of Storfjorden trough, western Barren Sea: a comparative study. Geol Rundsch 85:338-349

52. Lekens WAH, Sejrup HP, Haflidason H, Petersen GØ, Hjelstuen B, Knorr G (2005) Laminated sediments preceding Heinrich event 1 in the Northern North Sea and Southern Norwegian Sea: origin, processes and regional linkage. Mar Geol 216:27-50

53. Llopart J, Urgeles R, Camerlenghi A, Lucchi RG, De Mol B, Rebesco M, Pedrosa MT (2014) Slope Instability of Glaciated Continental Margins: Constraints from Permeability-Compressibility Tests and Hydrogeological Modeling Off Storfjorden, NW Barents Sea. In: Krastel S et al (eds) Submarine Mass Movements and Their Consequences, Advances in Natural and Technological Hazards Research, vol 37. Springer Science book series, pp 95-104

54. Llopart J, Urgeles R, Camerlenghi A, Lucchi, RG, Rebesco M, De Mol B (2015) Development of the Storfjorden and Kveithola Trough Mouth Fans, North-Western Barents Sea. Quat Sci Rev 129:68-84

55. López-Martínez J, Muñoz A, Dowdeswell JA, Linés C, Acosta J (2011) Relict sea-floor ploughmarks record deep-keeled Antarctic icebergs to $45^{\circ} \mathrm{S}$ on the Argentine margin. Mar Geol 288:43-48

56. Lubinski DJ, Korsun S, Polyak L, Forman SL, Lehman SJ, Herlihy FA, Miller GH (1996) The last deglaciation of the Franz Victoria Trough, northern Barents Sea. Boreas 25:89-100
57. Lucchi RG, Rebesco M (2007) Glacial contourites on the Antarctic Peninsula margins: insight for palaeoenvironmental and palaeoclimatic conditions. In: Viana AR Rebesco M (eds), Economic and Palaeosignificance of Contourite Deposits. Geol Soc London Special Publ 276:111-127

58. Lucchi RG, Camerlenghi A, Rebesco M et al (2013) Postglacial sedimentary processes on the Storfjorden and Kveithola TMFs: impact of extreme glacimarine sedimentation. Global Planet Change 111:309-326. doi:10.1016/j.gloplacha.2013.10.008

59. McElhinny MW, McFadden PL (1997) Palaeosecular variation over the past $5 \mathrm{Myr}$ based on a new generalized database. Geophys J Int 131(2):240-252

60. McFadden PL, Merrill RT, McElhinny MW (1988) Dipole/ quadrupole family modeling of palaeosecular variation. J Geophys Res 93(B10):11583-11588

61. Meyers PA (1994) Preservation of elemental and isotopic source identification of sedimentary organic matter. Chem Geol 114:289-302

62. Mitrovica JX, Tamisiea ME, Davis JL, Milne GA (2001) Recent mass balance of polar ice sheets inferred from patterns of global sea level change. Nature 409:1026-1029

63. Montaggioni LF, Cabioch G, Camoinau GF, Bard E, RibnaudLaurenti A, Faure G, Déjardin P, Récy J (1997) Continuous record of reef growth over the past $14 \mathrm{ky}$ on the mid-Pacific island of Tahiti. Geology 25:555-558

64. Pedrosa M, Camerlenghi A, De Mol B, Urgeles R, Rebesco M, Lucchi RG, Shipboard participants of the SVAIS and EGLACOM Cruises (2011) Seabed Morphology and Shallow Sedimentary Structure of the Storfjorden and Kveitehola TroughMouth Fans (north west Barents Sea). Mar Geol 286(1-4):65-81. doi:10.1016/j.margeo.2011.05.009

65. Peltier WR (2005) On the hemispheric origins ofmeltwater pulse 1a. Quat Sci Rev 24:1655-1671

66. Piper DJW, Pereira CPG (1992) Late Quaternary sedimentation in central Flemish Pass. Can J Earth Sci 29:535-550

67. Rae JWB, Sarnthein M, Foster GL, Ridgwell A, Grootes PM, Elliott T (2014) Deep water formationin the North Pacific and deglacial CO2 rise. Paleoceanography 29:645-667

68. Rasmussen TL, Thomsen E, Slubowska MA, Jessen S, Solheim A, Koç N (2007) Paleoceanographic evolution of the SW Svalbard margin $\left(76^{\circ} \mathrm{N}\right)$ since $20,00014 \mathrm{C}$ yr BP. Quat Res 67:100-114

69. Rebesco M, Liu Y, Camerlenghi A, Winsborrow M et al (2011) Deglaciation of the Barents Sea Ice Sheet - a swath bathymetric and sub-bottom seismic study from the Kveithola Trough. Mar Geol 279:141-147. doi:10.1016/j.margeo.2010.10.018

70. Reimer PJ, Baillie MGL, Bard E et al (2009) IntCal09 and Marine09 radiocarbon age calibration curves, 0-50,000 years cal BP. Radiocarbon 51:1111-1115

71. Rinterknecht VR, Clark PU, Raisbeck GM, Yiou F, Bitinas A, Brook EJ, Marks L (2006) The Last Deglaciation of the Southeastern Sector of the Scandinavian Ice Sheet. Science 311:1449-1452

72. Rüther DC, Bjarnadóttir LR, Junttila J, Husum K, Rasmussen TL, Lucchi RG, Andreassen K (2012) Pattern and timing of the northwestern Barents Sea Ice Sheet deglaciation and indications of episodic Holocene deposition. Boreas 41:494-512

73. Sagnotti L, Macrì $P$, Lucchi RG, Rebesco $M$, Camerlenghi $A$ (2011) A Holocene paleosecular variation record from the northwestern Barents Sea continental margin. Geochem Geophy Geosy 12(11):Q11Z33. doi:10.1029/2011GC003810

74. Sagnotti L, Macrì P, Lucchi RG (2015) Geomagnetic palaeosecular variation around $15 \mathrm{ka}$ ago from NW Barents Sea cores (south of Svalbard). Geophys J Int (in press)

75. Sarnthein M (2011) Northern Meltwater Pulse, CO2, and changes in Atlantic convection. Science 331:156-158 
76. Shepherd A, Wingham D, Payne T, Skvarca P (2003) Larsen Ice Shelf has progressively thinned. Science 302:856-859

77. Siegert MJ, Dowdeswell JA (2002) Late Weichselian iceberg, surface-melt and sediment production from the Eurasian Ice Sheet: results from numerical ice-sheet modelling. Marine Geol 188:109-127

78. Slubowska-Woldengen M, Koç N, Rasmussen TL, KlitgaardKristensen D, Hald M, Jennings AE (2008) Time-slice reconstructions of ocean circulation changes on the continental shelf in the Nordic and Barents Seas during the last 16,000 cal yr B.P. Quat Sci Rev 27:1476-1492

79. Slubowska-Woldengen M, Rasmussen TL, Koç N, KlitgaardKristensenc D, Nilsen F, Solheim A (2007) Advection of Atlantic Water to the western and northern Svalbard shelf since 17,500 cal yr BP. Quat Sci Rev 26:463-478

80. Slubowska MA, Koc N, Rasmussen TL, Klitgaard-Kristensen D (2005) Changes in the flow of Atlantic water into the Arctic Ocean since the last deglaciation: evidence from the northern Svalbard continental margin, 801N. Paleoceanography 20:PA4014

81. Stanford JD, Rohling EJ, Hunter SH, Roberts AP, Rasmussen SO, Bard E, McManus J, Fairbanks RG (2006) Timing of meltwater pulse 1a and climate responses to meltwater injections. Paleoceanography 21(4):PA4103. doi:10.1029/2006PA001340

82. Stuiver M, Reimer PJ (1993) Extended 14C database and revised CALIB radiocarbon calibration program. Radiocarbon 35:215-230

83. Tauxe L, Kent DV (2004) A simplified statistical model for the geomagnetic field and the detection of shallow bias in paleomagnetic inclinations: was the ancient magnetic field dipolar. Geophy Monogr Series 145:101-116

84. Thornalley DJR, Bauc HA, Gebbie G, Guo W, Ziegler M, Bernasconi SM, Barker S, Skinner LC, Yu J (2015) A warm and poorly ventilated deep Arctic Mediterranean during the last glacial period. Science 349(6249):706-710. doi:10.1126/science. aaa9554

85. Tripsanas EK, Piper DJW (2008) Late Quaternary stratigraphy and sedimentology of Orphane Basin: implications for meltwater dispersal in the southern Labrador Sea. Palaeogeogr Palaeoclimatol Palaeoecol 260:521-539

86. Vandamme D (1994) A new method to determine palaeosecular variation. Phys Earth Interiors 85:131-142

87. Vogt PR, Crane K, Sundvor E (1994) Deep Pleistocene iceberg ploughmarks on the Yermak Plateau: sidescan and $3.5 \mathrm{kHz}$ evidence for thick calving ice fronts and a possible marine ice sheet in the Arctic Ocean. Geology 22:403-406

88. Vorren TO, Hald M, Thomsen E (1984) Quaternary sediments and environments on the continental shelf off northern Norway. Mar Geol 57:229-257

89. Weaver AJ, Saenko OA, Clark PU, Mitrovica JX (2003) Meltwater Pulse 1A from Antarctica as a trigger of the BøllingAllerød warm interval. Science 299:709-1713

90. Weber ME, Clark PU, Kuhn G, Timmermann A, Sprenk D, Gladstone R, Zhang X, Lohmann G, Menviel L (2014) Millennial-scale variability in Antarctic ice-sheet discharge during the last deglaciation. Nature 510:134-138

91. Weber ME, Clark PU, Ricken W, Mitrovica JX, Hostetler SW, Kuhn G (2011) Interhemispheric ice-sheet synchronicity during the Last Glacial Maximum. Science 334:1265-1269

92. Webster JM, Clague DA, Riker-Coleman K, Gallup C, Braga JC, Potts D, Moore JG, Winterer EL, Paull CK (2004) Drowning of the -150 m reef off Hawaii: a casualty of global meltwater pulse 1A? Geology 32:249-252

93. Yokoyama Y, Lambeck K, De Deckker P, Johnston P, Fifield LK (2000) Timing of the last glacial maximum from observed sealevel minima. Nature 406:713-716 